\title{
Analisis Perupaan Situs Megalitik Gunung Padang di Cianjur, Jawa Barat
}

\author{
Savitri Putri Ramadina \\ Fakultas Seni Rupa dan Desain, Institut Teknologi Bandung, \\ Jalan Ganesa No. 10, Bandung 40132, Indonesia \\ Email: sp_ramadina@yahoo.com
}

\begin{abstract}
Abstrak. Situs megalitik Gunung Padang yang terdapat di Desa Karyamukti, Kecamatan Campaka, Cianjur, Jawa Barat merupakan situs peninggalan tradisi Megalitik terbesar di Asia Tenggara seluas $3132,15 \mathrm{~m}^{2}$. Situs yang terletak pada koordinat 6057'LS 10701'BT, sekitar 50 kilometer arah barat daya kota Cianjur, Jawa Barat tersebut berbentuk punden berundak yang terdiri dari lima buah teras. Penelitian ini dimaksudkan sebagai upaya untuk mengetahui bagaimana konstruksi arsitektur, bentuk perupaan, serta peran dan fungsi situs Gunung Padang. Penelitian dilakukan dengan metode kualitatif dan pendekatan multidisiplin, terutama dengan menggunakan teori sejarah seni rupa dan teori kritik seni. Berdasarkan penelitian, struktur keseluruhan situs merupakan struktur megalitik terbuka yang terbagi menjadi teras-teras berundak yang dibatasi kolom-kolom batu besar, dimana semakin ke atas luas teras-teras tersebut semakin mengecil. Beberapa hasil penelitian yang telah dilakukan sebelumnya menghasilkan asumsi bahwa situs Gunung Padang memiliki fungsi sebagai tempat pemujaan kepercayaan animisme yang umumnya dianut oleh masyarakat pendukung kebudayaan Megalitik serta sebagai tempat berkumpul para pemuka adat untuk mengadakan musyawarah. Pola tiga dan pola lima serta simbolsimbol kepercayaan Sunda Wiwitan digunakan dan terdapat pada konstruksi keseluruhan struktur-struktur yang ada pada situs Gunung Padang. Kemampuan untuk membangun sebuah konstruksi megalitik yang besar serta adanya penerapan pola pikir dan nilai estetika yang didasari pola pikir tersebut merupakan ciri bahwa masyarakat pembangun situs Gunung Padang telah memiliki kebudayaan yang tinggi.
\end{abstract}

Kata kunci: Gunung Padang; Megalitik; perupaan; prasejarah; Sunda.

Abstract. Gunung Padang megalithic site at Desa Karyamukti, Cianjur, West Java is the biggest Megalithic site in Southeast Asia and situated in an area of $3132.15 \mathrm{~m}^{2}$. The site, which is located at $6^{\circ} 057^{\prime} \mathrm{S} 107^{\circ} 01^{\prime} \mathrm{E}$ about 50 kilometer southwest of Cianjur city in West Java, is shaped in punden berundak or terraced site which consisted of five terraces. This study is intended to be an endeavor to comprehend the architectural construction, visualization, and purpose of Gunung Padang site. The research was done by qualitative analysis and multidiscipline approaches, especially by using the theories of art history and art criticism. Based on the research, the whole site is an open megalithic structure which then divided into terraces bordered by big stone columns, and the area of the terraces

Received April 24 ${ }^{\text {th }}, 2012$, Revised October $29^{\text {th }}, 2013$, Accepted for publication November $8^{\text {th }}, 2013$.

Copyright (C) 2013 Published by LPPM ITB, ISSN: 1978-3078, DOI: 10.5614/itbj.vad.2013.4.1.7 
is getting narrower toward the top of the site. Forerunner researches of Gunung Padang created assumptions that Gunung Padang site functioned as sacred place for animism ritual which was a common belief of Megalithic communities, and as a gathering place of chieftains for important discussions. The pattern of three and pattern of five, and symbols of Sunda Wiwitan applied in whole constructions and structures of Gunung Padang site. The abilities to build a majestic megalithic construction and the applications of aesthetic values and pattern of thoughts signifying that the people who built Gunung Padang site had advanced culture and civilization.

Keywords: civilization; Gunung Padang; Megalithic; prehistoric; Sunda; visualization.

\section{Pendahuluan}

Istilah Megalitik berasal dari bahasa Yunani megas yang berarti "besar" dan lithos yang berarti "batu". Periode Megalitik mencakup masa Neolitik dan Logam pada periode prasejarah. Meskipun demikian, istilah "megalitik" juga merujuk pada konstruksi-konstruksi atau monumen-monumen batu besar buatan manusia yang meskipun sebagian besar dibuat pada masa Neolitik dan zaman Logam, dapat ditemukan pula pada masa Mesolitik. Kepercayaan atau agama masyarakat pada masa itu umumnya menjadi dasar gagasan karya-karya seni Megalitik, termasuk dalam konstruksi dan perupaan monumen megalitik.

Situs Gunung Padang di Desa Karyamukti Kecamatan Campaka, Cianjur, Jawa Barat merupakan situs megalitik berbentuk punden berundak terbesar di Asia Tenggara. Situs Gunung Padang merupakan temuan peninggalan tradisi Megalitik yang baru. Uraian tentang peninggalan tradisi Megalitik di Gunung Padang ini pada masa sebelum tahun 1950 jarang ditemukan, baik dalam hasil penerbitan di dalam maupun di luar negeri [1]. Keberadaan situs ini pertama kali muncul dalam laporan Rapporten van de Oudheid-kundigen Dienst (ROD) tahun 1914, selanjutnya dilaporkan NJ Krom pada tahun 1949. Situs Gunung Padang mulai menjadi sorotan ketika tiga orang penduduk melaporkan penemuan situs ini pada tahun 1979.

Penelitian arkeologis yang telah dilakukan Pusat Penelitian Arkeologi Nasional dan Direktorat Sejarah dan Purbakala menghasilkan beberapa asumsi tentang fungsi dan peranan situs Gunung Padang bagi masyarakat penciptanya, yaitu masyarakat prasejarah masa Megalitik di daerah sekitar situs tersebut, yaitu sebagai monumen yang berkaitan dengan kegiatan keagamaan [2]. Asumsi tersebut diambil berdasarkan studi arkeologi maupun analogi etnografi pada komunitas masyarakat yang saat ini masih menerapkan kultur Megalitik. Cara pembuatan dan pendirian situs Gunung Padang memiliki sistem dan prosedur yang dapat dicari perbandingannya melalui studi arkeologi etnografi yang telah 
dilakukan pada komunitas Megalitik di Toraja dan Sumba, dimana masyarakat memiliki kesadaran yang tinggi untuk berpartisipasi dalam pembuatan bangunan-bangunan semacam itu. Pembangunan teras situs yang megah dengan cara gotong royong merupakan kesempatan bagi masyarakat untuk 'beramal' terhadap sistem kepercayaan mereka, selain sebagai upaya pendekatan rohani terhadap kekuatan gaib yang merupakan obyek sembahan mereka. Cara pembuatan yang dilakukan oleh ratusan atau bahkan ribuan orang dengan cara bergotong-royong juga dapat disaksikan seperti di Nias, situs Easter Island, atau situs Stone Henge di Inggris.

Perupaan ${ }^{1}$, yaitu proses, cara, perbuatan membentuk wujud, bentuk, atau bangun situs Gunung Padang serta tata cara peletakkan batuannya menyerupai situs Kiragawalariki di Atambua, Timor Barat, dan dengan teras-teras berundak di Kepulauan Pasifik [2]. Bentukan seperti itu disebut sebagai marae, yaitu struktur megalitik pada area yang telah dibersihkan dari pepohonan sehingga menyerupai tanah lapang. Area tersebut kemudian dibatasi dengan bebatuan dan satu batu diletakkan di tengah area sebagai "batu pusat". Meskipun demikian, perkiraan tentang perupaan situs Gunung Padang tersebut terutama mengenai aspek-aspek estetik di dalamnya saat ini belum memiliki kajian yang lebih intensif.

Berdasarkan asumsi bahwa situs Gunung Padang didirikan sebagai tempat pemujaan masyarakat prasejarah dengan perupaan situs yang diasumsikan memiliki elemen-elemen estetik khas tempat pemujaan kepercayaan primordial, terutama kepercayaan masyarakat era Megalitik menjadi latar belakang bagi kajian dan analisis dalam penelitian ini. Hasil penelitian diharapkan mampu memberikan informasi dan pemahaman baru mengenai local genius masyarakat prasejarah, terutama masyarakat primordial di daerah Jawa Barat, dan di masa mendatang akan memberikan kontribusi yang signifikan pada studi-studi mengenai sejarah seni rupa purbakala, terutama yang berkaitan dengan bentukbentuk rupa peninggalan purbakala.

\section{$2 \quad$ Situs Megalitik Gunung Padang}

Situs megalitik Gunung Padang merupakan bangunan berundak-undak atau biasa disebut dengan istilah 'punden berundak' yang terdiri dari lima teras atau tingkatan; dimana makin tinggi letak tingkat atau terasnya, luasnya makin menyempit. Istilah punden berasal dari bahasa Jawa yang berarti 'terhormat' dan berundak berarti 'bertingkat'. Struktur serupa dengan punden berundak

\footnotetext{
${ }^{1}$ Proses, cara, perbuatan membentuk wujud, bangun, atau bentuk (Moeliono, Anton M. 1988. Kamus Besar Bahasa Indonesia. Jakarta: 1988).
} 
Indonesia adalah marae yang terdapat di Kepulauan Pasifik Barat (lihat Gambar $1)$.

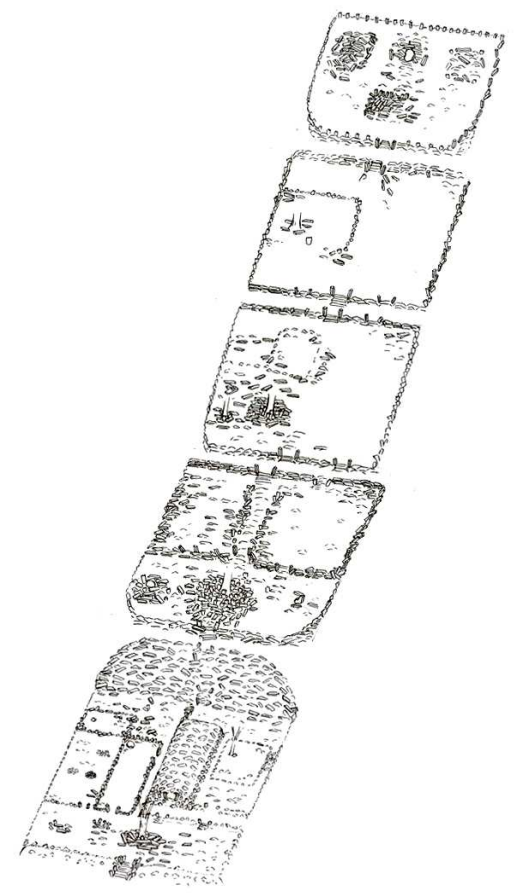

Gambar 1 Teras-teras Situs Gunung Padang.

Secara morfologis, Gunung Padang merupakan bukit kecil yang terletak di lereng utara pegunungan memanjang berarah barat laut-tenggara, dengan orientasi memanjang utara-selatan. Lokasi berada pada ketinggian sekitar 950 meter di atas permukaan laut. Situs ini terdiri dari lima teras pada wilayah yang berukuran lebar kurang lebih 20-40 meter dan panjang kurang lebih 130 meter. Struktur keseluruhannya adalah struktur megalitik terbuka yang terbagi atas teras-teras berundak yang dibatasi kolom-kolom batu besar. Semakin ke atas luas teras-teras situs Gunung Padang semakin mengecil. Rata-rata ukuran tiga buah teras teratas adalah $20 \times 20$ meter, teras kedua terbawah berukuran kurang lebih 25 x 30 meter, dan teras terbawah berukuran kurang lebih 35 x 40 meter.

Struktur situs Gunung Padang terdiri dari susunan kolom-kolom batu poligonal yang merupakan hasil bentukan dari proses pendinginan lava menjadi batuan beku berjenis andesit atau basalt. Proses fisik pembentukan kolom batu poligonal seperti yang digunakan pada situs Gunung Padang sama dengan proses yang membentuk bukit kolom batu poligonal Giant's Causeway di 
Irlandia, Devil's Tower di Yellowstone, Amerika Serikat, atau kolom-kolom batu di Gunung Selacau dan Lagadar di Cimahi Selatan, Indonesia. Sumber batu-batu penyusun ini diperkirakan merupakan hasil pembekuan magma dari gunung-gunung api purba di sekitar Gunung Padang pada masa Pleistosen awal, sekitar 21 juta tahun yang lalu. Keberadaan sumber alamiah batu-batu tersebut dapat dikenali melalui pengamatan terhadap kaki bukit Gunung Padang, dimana kolom-kolom batu alamiah yang bukan berasal dari reruntuhan situs masih berserakan [3].

\subsection{Teras I}

Teras pertama atau teras I mempunyai bentuk persegi empat. Sisi barat laut dan

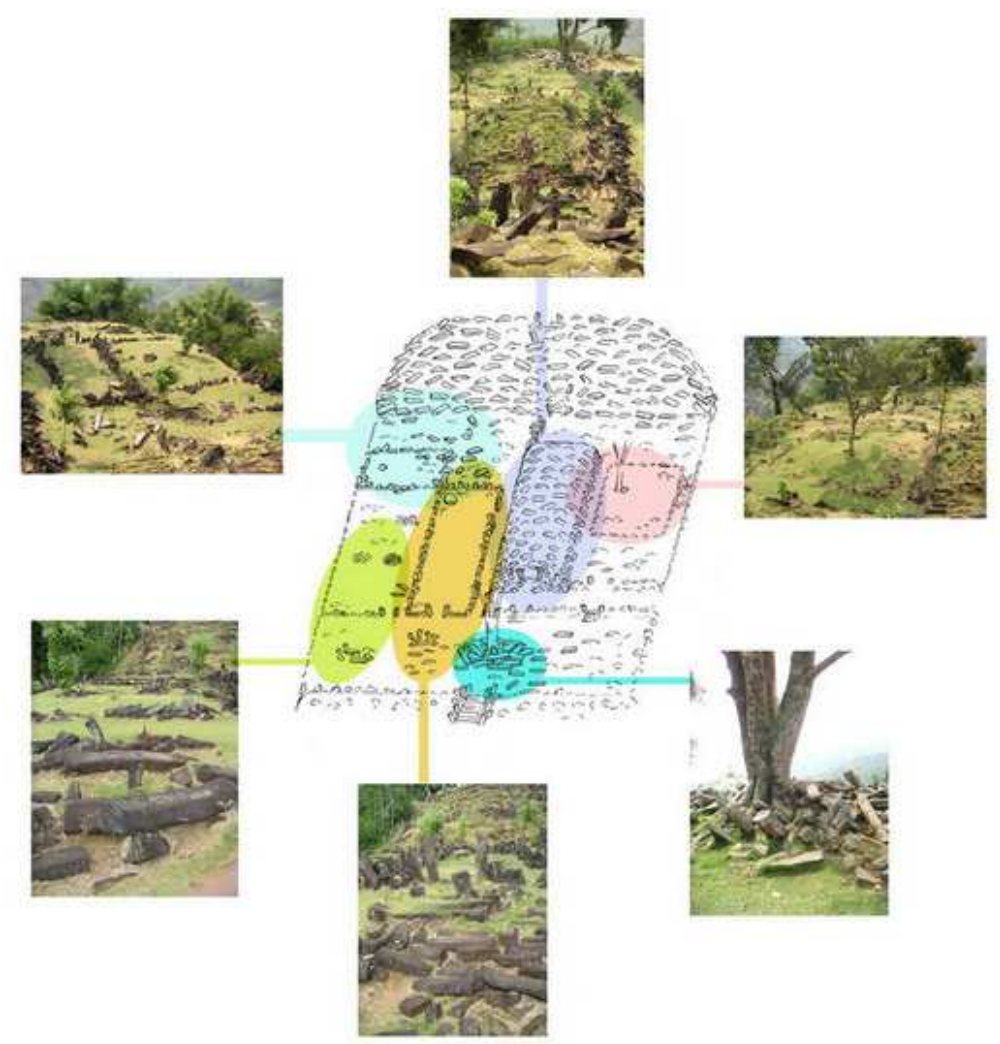

Gambar 2 Teras I Situs Gunung Padang.

tenggara teras ini memiliki ukuran yang berbeda; sisi barat laut berukuran panjang 40 meter, sisi tenggara berukuran panjang 36 meter, sementara kedua 
sisi lainnya masing-masing berukuran 28 meter [1]. Teras I merupakan teras terbesar sekaligus terletak paling bawah pada situs Gunung Padang. Dibandingkan dengan teras-teras yang lain, Teras I memiliki jumlah struktur paling banyak; sekitar 6 bentukan struktur dapat dikenali pada Teras I. Denah keseluruhan teras I dapat dilihat pada Gambar 2. Konstruksi teras I terbagi lagi ke dalam struktur bangunan atau batuan yang disusun membentuk formasi tertentu.

\section{$2.2 \quad$ Teras II}

Teras II memiliki kontur tanah yang lebih rata dari teras I. Sisi barat laut atau sisi depan teras II memiliki panjang 22,30 meter, sisi timur laut memiliki

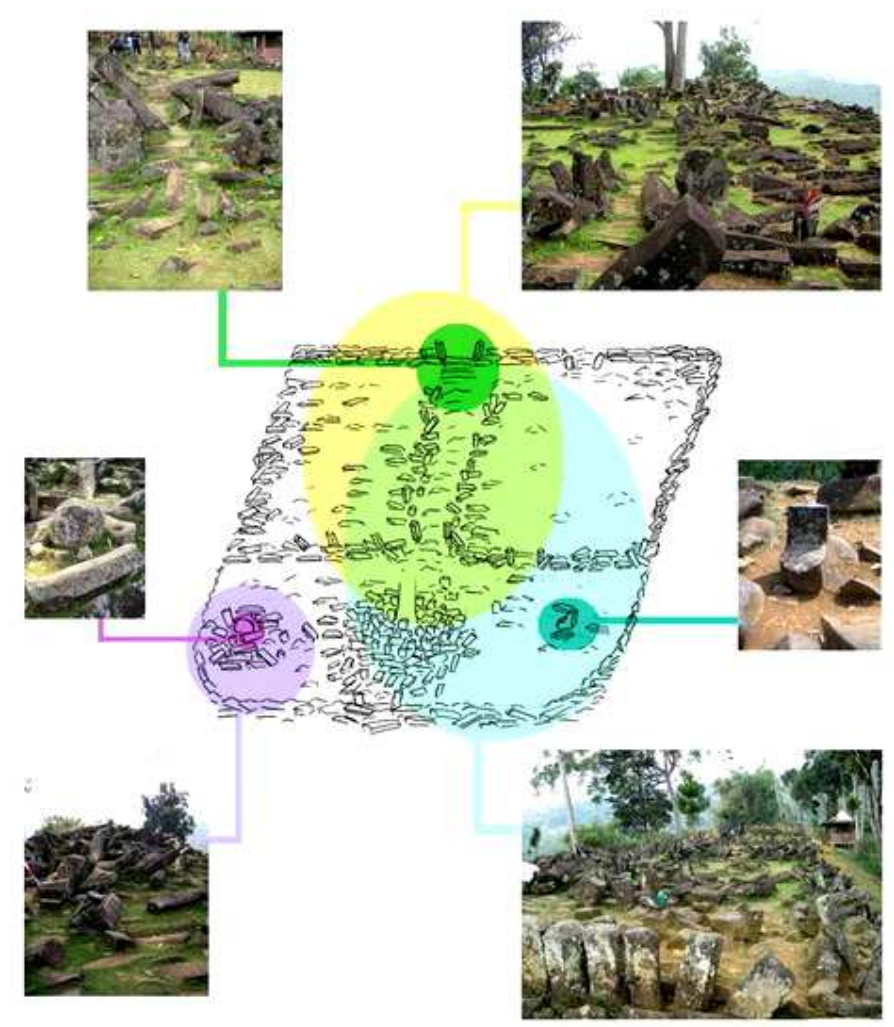

Gambar 3 Teras II Situs Gunung Padang.

panjang 25 meter, sisi barat daya memiliki panjang 24 meter, dan sisi tenggara atau belakang teras berukuran panjang 18,5 meter [1]. Pada teras II terdapat 
batu-batu tegak yang mempunyai ukuran lebih besar daripada batu batu tegak yang lain, berfungsi sebagai batas jalan atau 'pagar' antar area teras. Denah keseluruhan teras II dapat dilihat pada Gambar 3.

\subsection{Teras III}

Teras III berukuran lebih kecil daripada teras II. Sisi barat laut teras III memiliki panjang 18,5 meter, sisi tenggara dan timur laut 18 meter, dan sisi barat daya 18 meter. Laporan N.J Krom pada tahun 1914 mengasumsikan bahwa area teras III merupakan area pekuburan, meskipun hasil ekskavasi D.D. Bintarti pada tahun 1982 membuktikan hal sebaliknya. Ekskavasi D.D. Bintarti tersebut juga menemukan pecahan gerabah polos yang terbatas jumlahnya [1]. Denah keseluruhan teras III dapat dilihat pada Gambar 4.

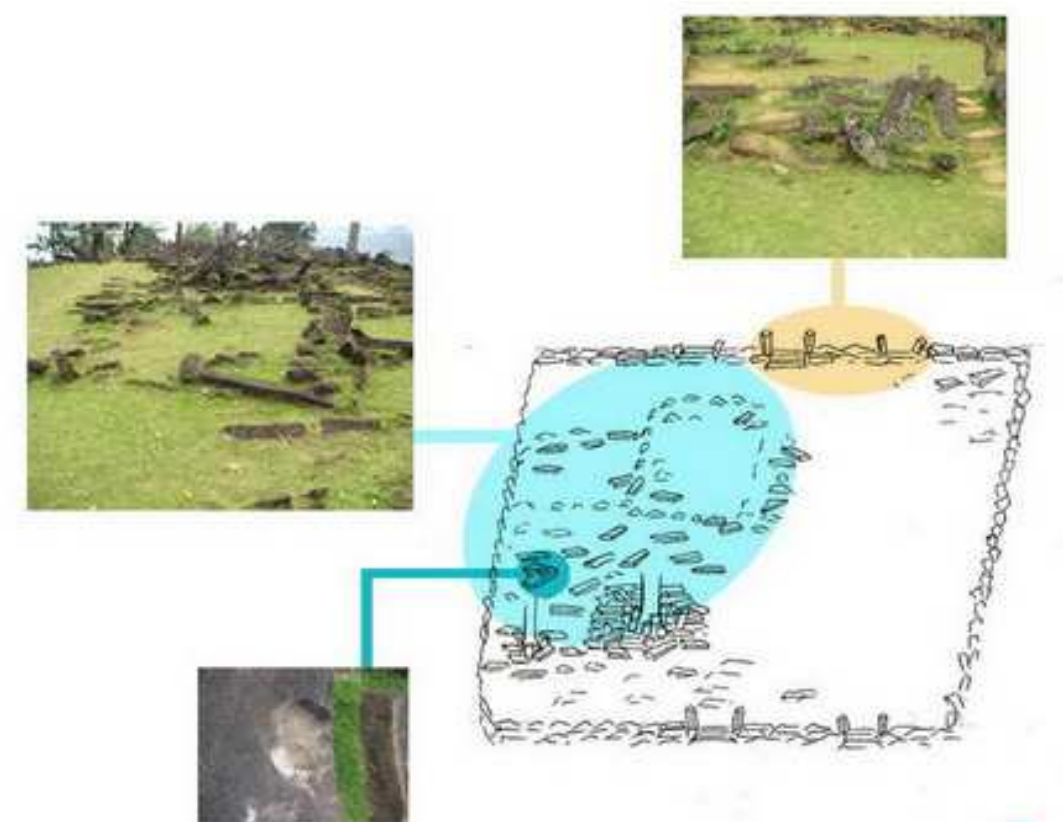

Gambar 4 Teras III Situs Gunung Padang.

\subsection{Teras IV}

Teras IV merupakan teras dengan jumlah struktur bangunan atau susunan batuan paling minim diantara teras-teras situs Gunung Padang. Teras IV memiliki luas area kurang lebih 20 x 16 meter [1]. Denah keseluruhan teras IV dapat dilihat pada Gambar 5. 


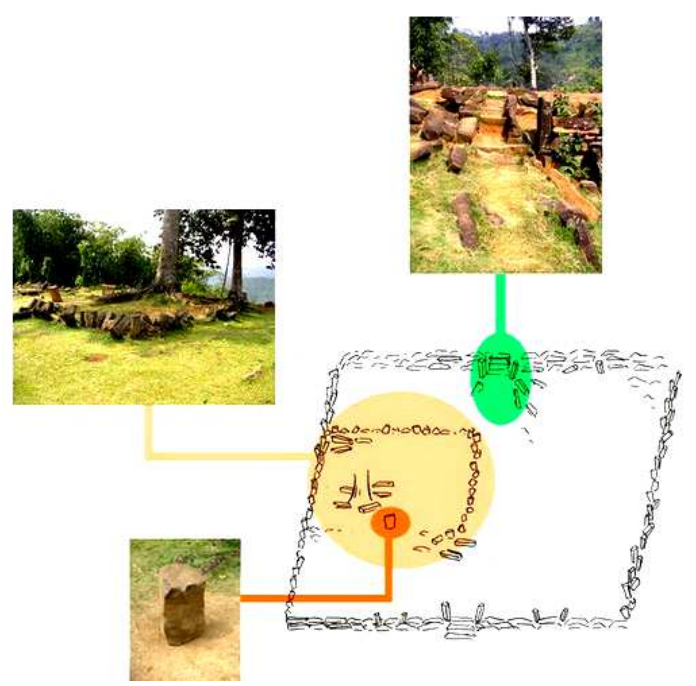

Gambar 5 Teras IV Situs Gunung Padang.

\subsection{Teras $\mathrm{V}$}

Teras V merupakan teras tertinggi situs Gunung Padang yang terletak di Bagian

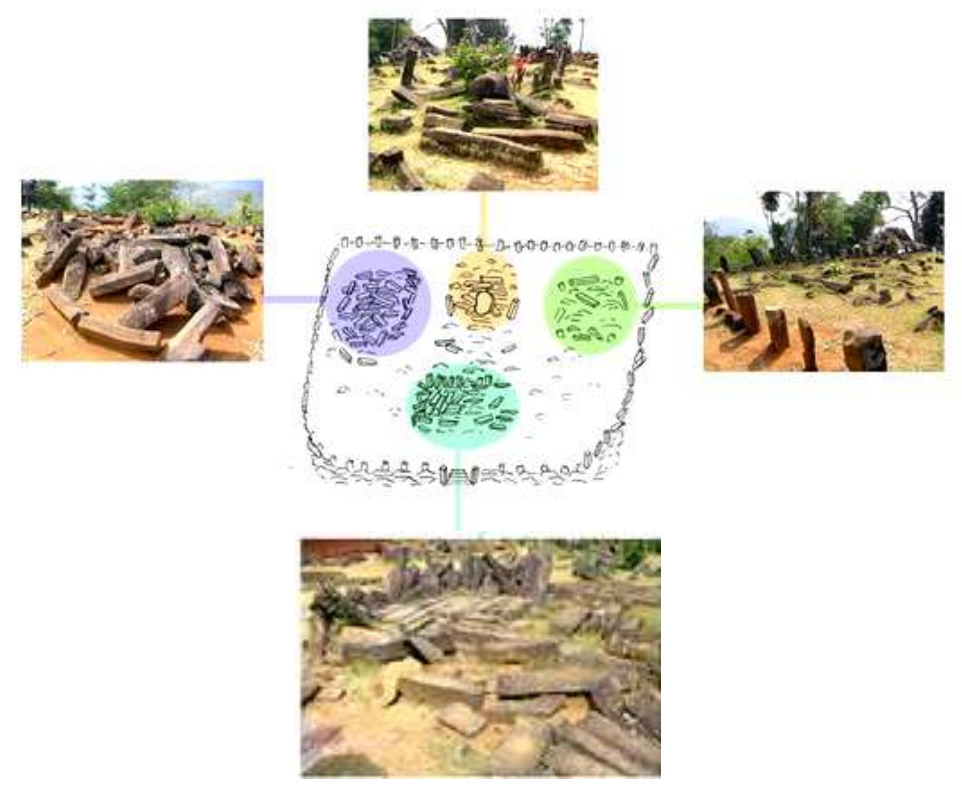

Gambar 6 Teras V Situs Gunung Padang. 
paling ujung sebelah tenggara. Sisi barat laut memiliki panjang 17,5 meter, sisi timur laut 19 meter, sisi tenggara 16 meter dan sisi barat daya 19 meter [1]. Di bagian tengah atas teras terdapat batu-batuan yang disusun seperti altar berukuran kurang lebih $3 \times 3$ meter. Di bagian kanan dan kiri 'altar' tersebut terdapat susunan bebatuan membentuk persegi dengan ukuran sekitar $3 \times 3$ meter (Gambar 6).

\subsection{Tipe Struktur Bangunan}

Konstruksi situs megalitik Gunung Padang terdiri dari berbagai tipe struktur. Meskipun demikian dari struktur-struktur yang ada dan mampu diamati oleh penulis, dapat ditelaah pola-pola struktur dasar yang terdapat pada konstruksi situs Gunung Padang. Pada Tabel 1 berikut dijabarkan tipe-tipe struktur dari bentukan yang paling umum dijumpai hingga struktur yang paling khas pada konstruksi situs Gunung Padang berdasarkan kategorisasi penulis:

Tabel 1 Tabel Tipe Struktur Penyusun Situs Gunung Padang.

\begin{tabular}{|c|c|c|c|}
\hline No. & $\begin{array}{l}\text { Nama } \\
\text { Tipe }\end{array}$ & Struktur Dasar & Keterangan \\
\hline I & Kamar I & की & $\begin{array}{l}\text { - Umumnya dibentuk dari batu } \\
\text { bentuk silinder yang disusun rapat } \\
\text { dengan batu kolom persegi panjang } \\
\text { sebagai penanda bagian 'pintu } \\
\text { kamar', atau dari batu silinder dan } \\
\text { kolom yang diletakkan berselang- } \\
\text { seling } \\
\text { - Batu ditanam tegak di tanah } \\
\text { - Bentuk kamar umumnya persegi } \\
\text { panjang }\end{array}$ \\
\hline II & Kamar II & 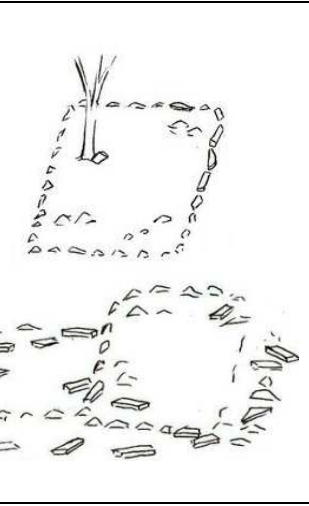 & $\begin{array}{l}\text { - Umumnya dibentuk dari batu } \\
\text { silinder yang disusun sedikit } \\
\text { berjarak satu sama lain dan tidak } \\
\text { memiliki 'pintu' } \\
\text { - Batu ditanam mendatar di tanah } \\
\text { - Bentuk kamar umumnya bujur } \\
\text { sangkar atau persegi } \\
\text { - Biasanya didapati satu pohon di } \\
\text { - dalam 'kamar' } \\
\text { - Umumnya terdapat batu kolom } \\
\text { persegi panjang yang tertanam atau } \\
\text { tertimbun mendatar di bagian pojok } \\
\text { 'kamar' }\end{array}$ \\
\hline
\end{tabular}




\begin{tabular}{|c|c|c|c|}
\hline No. & $\begin{array}{l}\text { Nama } \\
\text { Tipe }\end{array}$ & Struktur Dasar & Keterangan \\
\hline III & $\begin{array}{l}\text { Struktur } \\
\text { Kompak }\end{array}$ & 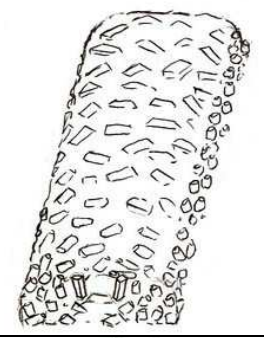 & $\begin{array}{l}\text { - Dibentuk dari batu kolom } \\
\text { persegi panjang yang disusun } \\
\text { menumpuk membentuk 'bukit' } \\
\text { atau tumulus } \\
\text { - Bentuk bangunan persegi } \\
\text { panjang }\end{array}$ \\
\hline IV & $\begin{array}{l}\text { Lingkaran } \\
\text { Kompak }\end{array}$ & हैं二 898 & $\begin{array}{l}\text { - Terdiri dari batu kolom dan } \\
\text { silinder yang disusun } \\
\text { mengelilingi pohon, atau terdiri } \\
\text { dari batu-batu kecil yang } \\
\text { ditumpuk membentuk cycoliths } \\
\text { atau cairn } \\
\text { - Membentuk formasi lingkaran } \\
\text { atau elips } \\
\text { - Umumnya batu diletakkan } \\
\text { mendatar di tanah, dengan batu } \\
\text { kolom berada di lingkar luar dan } \\
\text { batu silinder di lingkar dalam } \\
\text { dekat dengan pohon }\end{array}$ \\
\hline V & $\begin{array}{l}\text { Kumpulan } \\
\text { Lempeng }\end{array}$ & 乎 & $\begin{array}{l}\text { Terdiri dari batu kolom } \\
\text { persegi panjang } \\
\text { - } \quad \text { Batu diletakkan mendatar di } \\
\text { tanah atau ditumpuk } \\
\text { - } \quad \text { Kadang dibatasi batu kolom } \\
\text { yang ditanam tegak } \\
\text { - } \quad \text { Bentuk persegi panjang }\end{array}$ \\
\hline
\end{tabular}

Situs Gunung Padang memiliki kemiripan konstruksi dengan beberapa situssitus megalitik lainnya yang terdapat di daerah Jawa Barat. Struktur yang serupa dengan struktur tipe I dan II dapat dijumpai pada situs Lemah Duhur yang juga terletak di daerah Cianjur dan pada situs Arca Domas di daerah Banten. Situs Lemah Duhur merupakan situs megalitik yang berbentuk punden berundak dengan lima teras seperti situs Gunung Padang. Bentuk keseluruhan struktur- 
struktur pada situs Lemah Duhur menyerupai struktur tipe I dan II pada situs Gunung Padang, yaitu petak persegi yang dibatasi batu-batu tegak.

\section{Pola Estetika Masyarakat Sunda dan Perupaan Situs Gunung Padang}

Jumlah teras pada situs Gunung Padang terdiri dari lima teras. Dunia manusia dalam kosmologi Sunda disebut Buana Panca Tengah, dimana panca berarti "lima" [4]. Berdasarkan hal tersebut, dapat diasumsikan bahwa situs megalitik Gunung Padang mengandung makna simbolik mengenai tahap-tahap yang dilakukan oleh jelema atau manusia biasa untuk menjadi manusa atau manusia sempurna.
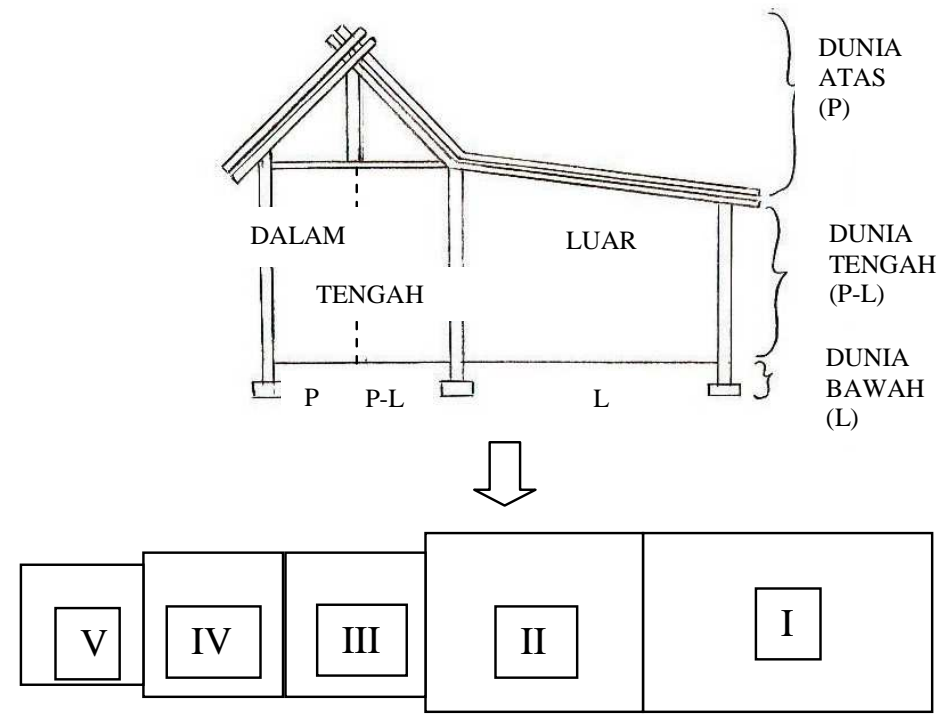

Gambar 7 Perbandingan Pembagian Ruang Rumah Adat Sunda dengan Peletakan Teras Situs Gunung Padang (diadaptasi dari Sumardjo [5]).

Satu hal yang dapat dicermati melalui peletakan teras-teras pada situs Gunung Padang secara keseluruhan adalah adanya penerapan sistem pembagian ruang seperti yang terdapat pada rumah adat Sunda [5]. Perhatikan Gambar 7 dan Tabel 2.

Dari Gambar 7 dan Tabel 2, dapat dilihat bagaimana pembagian teras situs Gunung Padang memiliki kesamaan dengan pembagian ruang pada rumah adat Sunda. Semakin ke 'dalam', elemen-elemen pada teras situs semakin mengandung simbol perempuan. Teras I di 'depan' didominasi oleh simbol laki- 
laki; teras-teras 'antara' yaitu Teras II, III, dan IV mengandung percampuran simbol laki-laki dan perempuan; sementara Teras $\mathrm{V}$ yang terletak paling 'dalam' didominasi simbol perempuan.

Tabel 2 Teras Situs Gunung Padang dan Elemen-elemennya.

\begin{tabular}{|c|c|}
\hline Teras & Elemen \\
\hline I & $\begin{array}{l}\text { Banyak terdapat struktur tipe I dengan tipe batu kolom persegi panjang } \\
\text { yang menyerupai lingga atau simbol laki-laki. }\end{array}$ \\
\hline II & $\begin{array}{l}\text { Konstruksi teras umumnya terdiri dari campuran struktur tipe I dan II } \\
\text { serta penggunaan batu kolom persegi panjang dan silinder yang } \\
\text { diletakkan vertikal (menyerupai lingga atau simbol laki-laki) dan } \\
\text { diletakkan horizontal (simbol perempuan). }\end{array}$ \\
\hline III & $\begin{array}{l}\text { Umum dijumpai struktur tipe II dengan batu kolom persegi panjang atau } \\
\text { silinder yang diletakkan horizontal (simbol perempuan) meski masih ada } \\
\text { batu yang diletakkan secara vertikal (simbol laki-laki). }\end{array}$ \\
\hline IV & $\begin{array}{l}\text { Terdapat struktur tipe II dengan batu tipe silinder. Meski batu tipe silinder } \\
\text { diletakkan vertikal, bentuk batu cenderung 'bulat' yang merupakan } \\
\text { simbol perempuan. }\end{array}$ \\
\hline V & $\begin{array}{l}\text { Terdiri dari struktur tipe } \mathrm{V} \text { dengan batu kolom persegi panjang atau } \\
\text { silinder yang diletakkan horizontal (simbol perempuan). }\end{array}$ \\
\hline
\end{tabular}

\section{$4 \quad$ Peran dan Fungsi Situs Gunung Padang}

Situs megalitik Gunung Padang memiliki kemiripan konstruksi dengan situs Lemah Duhur di Cianjur dan situs Arca Domas di daerah Banten, Jawa Barat serta marae yang umum dijumpai di kawasan Kepulauan Pasifik. Berdasarkan kemiripan konstruksi tersebut, dapat diperkirakan bagaimana peran dan fungsi situs Gunung Padang bagi masyarakat pembuatnya dengan bertolak pada fungsi situs Lemah Duhur, situs Arca Domas, dan marae.

Punden berundak Arca Domas atau Sasaka Domas bagi komunitas Baduy di Banten, Jawa Barat merupakan tempat pemujaan yang disakralkan dan hanya boleh dimasuki setahun sekali pada bulan Kalima atau pada saat upacara muja. Upacara muja dilaksanakan setiap tanggal 16, 17, dan 18 pada bulan Kalima penanggalan Baduy. Awal prosesi upacara dilakukan pada pagi hari tanggal 17 bulan Kalima di teras pertama. Upacara tersebut dipimpin oleh puun Cikeusik dengan membacakan mantra-mantra dan doa-doa tertentu sampai tengah hari, kemudian dilanjutkan dengan membenahi pelataran dan susunan batu yang berserakan hingga ke puncak teras. Begitu sampai di bagian puncak, peserta ritual upacara kemudian menyucikan muka, tangan, dan kaki pada sebuah batu lumpang yang disebut Sanghyang Pangumbaran. 
Sebagai tempat sakral atau kabuyutan bagi masyarakat Baduy, Arca Domas terletak di bagian paling selatan atau paling 'dalam' dalam sistem orientasi kampung Baduy (perhatikan Gambar 8). Letaknya sebagai kabuyutan tersebut juga menyebabkan masyarakat Baduy meyakini bahwa Arca Domas merupakan tempat berkumpul para karuhun atau roh-roh leluhur mereka. Hal ini menyerupai kepercayaan animisme dimana roh leluhur berada di tempat tinggi seperti bukit atau gunung, dalam hal ini kabuyutan tempat Arca Domas berada.

Situs Lemah Duhur merupakan bangunan megalitik berundak yang terletak di Desa Sukajembar, Cianjur pada sebuah dataran tinggi setinggi 941 meter di atas permukaan laut. Situs ini terdiri dari lima teras dan berorientasi utara-selatan. Teras I terletak di bagian selatan, sementara Teras V yang merupakan teras paling tinggi terletak di utara. Seperti pada situs Gunung Padang, teras-teras pada situs Lemah Duhur semakin ke atas ukurannya semakin mengecil. Halaman Teras I dan II merupakan halaman yang paling luas dibandingkan dengan teras-teras atas.

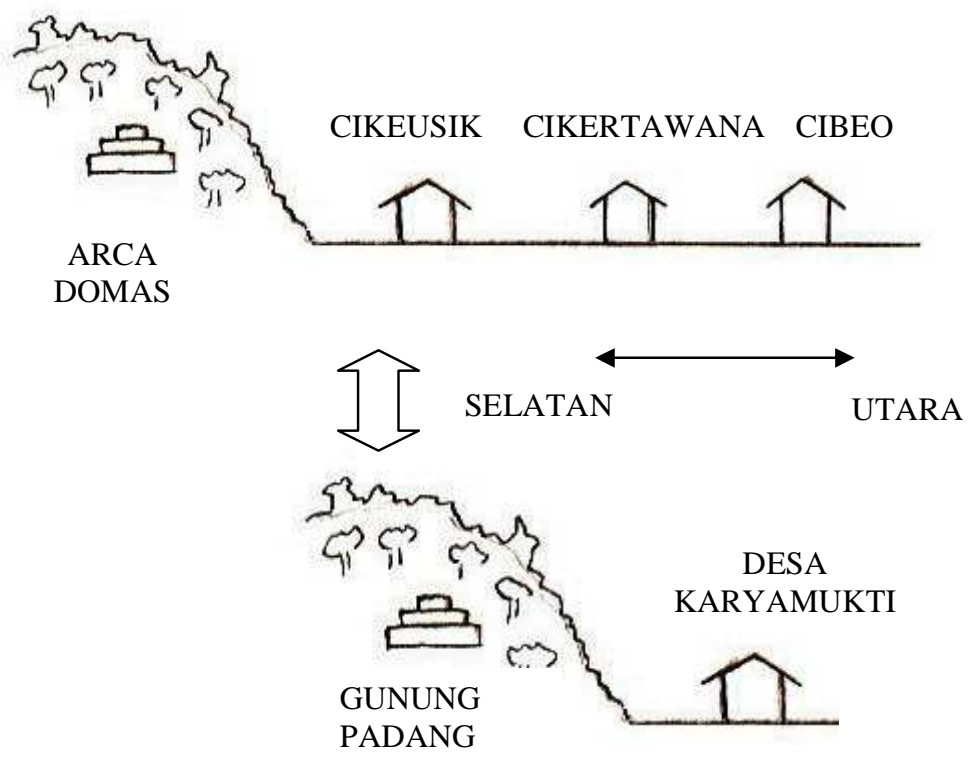

Gambar 8 Perbandingan Letak Punden Berundak Arca Domas dengan Pemukiman Baduy dan Situs Gunung Padang dengan Desa Karyamukti (diadaptasi dari Sumardjo [4]).

Dalam Peninggalan Tradisi Megalitik di Daerah Cianjur, Jawa Barat (2001), Haris Sukendar mengemukakan hipotesis bahwa halaman Teras I dan II 
digunakan sebagai tempat berkumpul bagi pengikut upacara pemujaan pada situs Lemah Duhur, baik yang mencakup upacara pertanian atau upacara lain, seperti upacara pertanian yang dilakukan oleh masyarakat Kanekes di daerah Banten Selatan, Jawa Barat. Teras III pada situs Lemah Duhur memiliki beberapa bangunan dari batu kali yang disusun dari batu-batu kali membentuk persegi panjang (kemungkinan menyerupai struktur I dan II pada situs Gunung Padang), dan oleh Haris Sukendar diasumsikan sebagai tempat musyawarah masyarakat Megalitik pada masa itu.

Bagi masyarakat Polinesia, marae merupakan tempat yang disakralkan dan memiliki dua fungsi, yaitu fungsi sosial sebagai tempat pertemuan suku sekaligus fungsi religius sebagai tempat pelaksanaan upacara yang berkaitan dengan kepercayaan mereka. Sementara itu marae dalam kebudayaan masyarakat Maori di daerah Selandia Baru merupakan istilah bagi lapangan yang dipagari yang terletak di depan wharenui (berarti "rumah besar"; merupakan bangunan tempat berkumpul masyarakat Maori). Marae merupakan tempat dilangsungkannya powhiri, yaitu upacara penyambutan yang menampilkan pidato, dan juga kegiatan-kegiatan lain yang berkaitan dengan kebudayaan dan kepercayaan masyarakat setempat seperti upacara pernikahan atau upacara kematian.

Berdasarkan fungsi situs Lemah Duhur, situs Arca Domas, dan marae tersebut, situs Gunung Padang bagi masyarakat primordial Sunda kemungkinan berfungsi terutama sebagai tempat upacara pemujaan sekaligus tempat berkumpul bagi para tetua adat. Asumsi tersebut diambil berdasarkan pemikiran berikut:

1. Masyarakat Baduy yang membangun situs Arca Domas dan masyarakat pembangun situs Gunung Padang merupakan masyarakat Sunda yang memiliki basis pola pikir dan sistem kepercayaan yang serupa. Baik Arca Domas maupun situs Gunung Padang didirikan di sebuah bukit, dan pada teras teratas terdapat obyek yang dianggap sakral (Arca Domas pada situs Arca Domas dan Batu Tahta pada situs Gunung Padang). Berdasarkan hal tersebut, dapat diasumsikan bahwa situs Gunung Padang memiliki fungsi sebagai tempat pemujaan bagi masyarakat pembuatnya.

2. Situs Lemah Duhur dan situs Gunung Padang sama-sama terletak di daerah Cianjur dan keduanya memiliki arsitektur serupa, dan seperti situs Arca Domas, situs Lemah Duhur dan situs Gunung Padang juga didirikan pada tempat tinggi. Berdasarkan hal tersebut, ada kemungkinan bahwa masyarakat pembangun kedua situs tersebut merupakan masyarakat Sunda primordial dari era yang sama dengan pola pikir dan sistem kepercayaan yang seragam. 
3. Masyarakat Sunda primordial yang membangun situs Gunung Padang merupakan bagian dari masyarakat pendukung tradisi Megalitik yang terdiri dari bangsa Austronesia, Melayu Polinesoide, dan Papua Melanosoide. Masyarakat Polinesia dimana marae banyak ditemukan merupakan bagian dari bangsa Austronesia. Adanya kemiripan konsep dan pola pikir antar masyarakat Sunda dan masyarakat Polinesia cukup besar, sehingga dapat ditarik asumsi bahwa fungsi situs Gunung Padang yang memiliki konstruksi serupa dengan marae adalah sebagai tempat berkumpul tetua adat.

\section{$5 \quad$ Kesimpulan}

Berdasarkan data yang berhasil dikumpulkan dan dipaparkan oleh penulis, kesimpulan yang dapat ditarik dari penelitian mengenai "Analisis Perupaan Situs Megalitik Gunung Padang di Cianjur, Jawa Barat" adalah sebagai berikut:

1. Situs megalitik Gunung Padang merupakan punden berundak yang digunakan untuk upacara-upacara yang berkaitan dengan sistem kepercayaan masyarakat prasejarah, terutama masyarakat Sunda primordial serupa dengan fungsi situs Arca Domas di Banten, Jawa Barat dan situs Lemah Duhur di Cianjur, Jawa Barat. Hal ini tercermin dalam bentuk peletakan lokasi situs yang didasari konsep pola kosmis pemukiman Sunda serta bentuk konstruksi situs berupa punden berundak yang umumnya digunakan sebagai konstruksi untuk tempat sakral dan upacara ritual.

2. Struktur-struktur pada situs megalitik Gunung Padang cenderung disusun dari batu kolom persegi panjang yang menyerupai perupaan menhir yang umum dijumpai pada situs-situs Megalitik seperti marae di Kepulauan Pasifik Barat. Persamaan 'gaya' dalam konstruksi tersebut menandakan bahwa situs Gunung Padang merupakan bagian dari sebuah kebudayaan Megalitik yang lebih besar, yaitu kebudayaan Megalitik Asia-Pasifik.

3. Perupaan pada situs megalitik Gunung Padang mengandung makna-makna simbolik serta nilai-nilai estetik yang terdapat pada pemikiran masyarakat Sunda. Simbol-simbol dalam estetika Sunda berasal dari sistem kepercayaan primordial mereka yaitu Sunda Wiwitan, sementara estetika Sunda sendiri merupakan asimilasi estetika pola tiga dengan estetika pola lima. Contoh aplikasi simbol dapat dilihat pada Teras V dengan strukturstruktur yang menyimbolkan hierarki Sang Hyang dalam kepercayaan Sunda Wiwitan yang dianut masyarakat Sunda sejak masa lampau dengan perupaan. Contoh penerapan bentuk visual dari estetika pola tiga dan lima Sunda tercermin pada elemen tritangtu (pola tiga) pada Teras I dan adanya bentukan menyerupai mandala pada struktur yang terdapat di Teras I.

4. Masyarakat Sunda pada masa Megalitik pada saat situs Gunung Padang dibangun telah memiliki kebudayaan yang tinggi; dicirikan melalui kemampuan untuk membangun sebuah konstruksi situs megalitik yang 
besar dan kompleks, didasari oleh konsep-konsep estetika Sunda yang terdiri dari estetika pola tiga dan lima serta simbol mandala, lingga, dan yoni yang terdapat pada sistem kepercayaan yang dianut.

5. Situs megalitik Gunung Padang merupakan representasi kebudayaan masyarakat Sunda pembuatnya. Hal ini tercermin dari peletakan teras-teras situs dimana Teras I yang berada di bagian depan atau bagian 'laki-laki' memiliki tipe rupa batu menyerupai lingga atau batu vertikal paling banyak sementara Teras V di bagian paling belakang atau bagian 'wanita' terdiri dari tipe rupa batu yang diletakkan horizontal yang merupakan lambang wanita. Pola peletakan tersebut terdapat pada pembagian ruang dalam rumah masyarakat Sunda.

Kesimpulan pada penelitian ini masih merupakan asumsi-asumsi sementara. Diperlukan data yang lebih akurat mengenai masa atau waktu pembuatan situs Gunung Padang bagi penelitian selanjutnya, mengingat kebudayaan Megalitik mencakup rentang waktu yang panjang dari masa Neolitik hingga zaman Logam dimana pengaruh kebudayaan dan agama lain seperti Hindu dan Buddha mulai masuk ke Indonesia, sehingga dapat ditelaah bagaimana pengaruh elemenelemen tersebut dalam kebudayaan dan kepercayaan Sunda kuno memang terkandung dalam perupaan situs Gunung Padang atau tidak.

\section{Referensi}

[1] Sukendar, Hs. 2001. Peninggalan Tradisi Megalitik di Daerah Cianjur, Jawa Barat. Jakarta: Departemen Kebudayaan dan Pariwisata.

[2] Dinas Kebudayaan dan Pariwisata Jawa Barat. 2002. Workshop Pelestarian dan Pengembangan Kawasan Situs Gunung Padang, Cipanas-Cianjur. Agustus 2002. Bandung: Dinas Kebudayaan dan Pariwisata Jawa Barat.

[3] Brahmantyo, B. 2006. Keagungan Situs Megalitik Gunung Padang. Pikiran Rakyat, 20 Januari 2006.

[4] Sumardjo, J. 2003. Simbol-simbol Artefak Budaya Sunda: Tafsir-Tafsir Pantun Sunda, Bandung: Kelir.

[5] Sumardjo, J. 2006. Estetika Paradoks, Bandung: Sunan Ambu Press. 